\title{
FOOD PREFERENCE OF RHESUS MONKEY MACACA MULATTA DURING THE PRE-MONSOON AND MONSOON SEASON AT PAKHUI WILDLIFE SANCTUARY, ARUNACHAL PRADESH
}

\author{
Awadhesh Kumar and G.S. Solanki \\ Department of Applied Science (Forestry), North Eastern Regional Institute of Science and Technology, Nirjuli, Arunachal Pradesh 791109, \\ India.
}

\begin{abstract}
Food preference of Rhesus Macaques (Macaca mulatta) in the wild was studied in semi-deciduous and tropical semi-evergreen forest of Pakhui Wildlife Sanctuary in East Kameng District of Arunachal Pradesh, India during the pre-monsoon and monsoon seasons. A group of 25 Rhesus Macaques of different age and sex classes was observed. Data was collected using group scan method. Rhesus Macaques ate 25 plant species, with a preference for 10 species and the order of preference varied in different months. Highly preferred plant species were Udal (Sterculia villosa), Pipal (Ficus religiosa), Jutali (Altingia excelsa), Panijamun (Syzygium syzygioides) and climbers. The monkeys primarily fed on young leaves, mature leaves, fruits, flowers, flower buds, petioles and seeds during study.
\end{abstract}

\section{Keywords}

Food, Macaca mulatta, preference, Rhesus Macaque

\section{Introduction}

Rhesus Macaque Macaca mulatta (Zimmermann, 1780) is distributed in India, Afghanistan, Pakistan, Nepal, Myanmar, Bangladesh, China, Vietnam, Thailand, Cambodia, and Laos (Srivastava, 1999). In India, it occurs in southern Himalaya, northeastern frontier including Assam, northern and southern India up to the river Godavari in the west and up to river Tapti (Prater, 1971; Tiwari \& Mukharjee, 1992). It is a semi-wild species in northern parts of India. Large troops live in and around villages, towns, sacred groves and temples. In jungles, they usually remain in the periphery and rarely penetrate into the depths, except when they move to seek denser cover (Prater, 1971).
The food preference of the Rhesus Macaque varies according to the habitat and seasonal availability of food. A preferred food species is defined as one that is utilized proportionally more frequently compared to its availability and high intensity of feeding on the species. Knowledge about the diet composition and food preference is essential for rational planning for habitat management. Urban Rhesus populations have been studied by several authors (Neville, 1968; Lindburg, 1971; Makwana, 1978, 1979; Goldstein \& Richard, 1989; Seth, et al., 1992; Mandal, 1995). The present study addresses the food preferences of Rhesus Macaques in Pakhui Wildlife Sanctuary during the premonsoon and monsoon seasons. Large part of the summer remains wet.

\section{Materials and Methods}

Pakhui Wildlife Sanctuary $\left(26^{\circ} 55^{\prime}-27^{\circ} 15^{\prime} \mathrm{E} \& 92^{\circ} 35^{\prime}-93^{\circ} 10^{\prime} \mathrm{N}\right)$ is situated in East Kameng District of Arunachal Pradesh. It covers an area of $861.95 \mathrm{~km}^{2}$. The terrain is primarily hilly with elevations ranging from 200 to $2000 \mathrm{~m}$. Pakhui Wildlife Sanctuary is one of the richest habitat in terms of biodiversity and naturally protected areas in the foothills of this state. Bhareli River in the West and Pakke River in the east form its boundaries. The southern part of the Sanctuary has common boundaries with Nameri National Park, Assam. The annual average rainfall is approximately $2500 \mathrm{~mm}$. Average minimum temperature of the area is $12^{\circ} \mathrm{C}$ and maximum $36^{\circ} \mathrm{C}$. The humidity is $70 \%$ to $80 \%$ except in winter months. The vegetation is mainly tropical semievergreen with several evergreen patches as well as semideciduous forests. Canes and palms are common in the moist areas.

The methods employed were based on direct observations. One group (25 individuals) of Rhesus Macaques of different ages and sex was chosen for the study. Observations were recorded daily from dawn to dusk in pre-monsoon and monsoon seasons (March 2001 to August 2001) for ten days continuously in each 
month. Time spent on eating major food plants and their parts was recorded using group scan sampling method (Altmann, 1974) at five minutes intervals. The observation sessions were divided into three intervals including morning (0700-1000hr), noon (1100-1300hr) and evening (1430-1830hr). Detailed observations were made using binoculars and telescopes.

\section{Results and Discussions}

Rhesus Macaques are diurnal, mostly terrestrial and partly arboreal (Rowe, 1996). The monkeys consumed 25 different plant species (Table 1) and ate young leaves, mature leaves, flowers, flower buds, fruits and petioles of a variety of trees, shrubs and climbers. The fruits of Altingia excelsa, Syzygium cumini, Syzygium syzygioides, Ficus racemosa and Ficus bengalensis and leaves of Ficus racemosa, Kydia calycina, Gmelina arborea, Okani nimora (unidentified tree), Syzygium cumini, Emblica officinalis and Mikania micrantha and flowers of Sterculia villosa, Bombax ceiba, Kydia calycina, Mangifera indica, Syzygium cumini etc. were eaten mainly. Time devoted for feeding on different species in each month was estimated in terms of percentage feeding time on the species (Table 2). It is seen from the table that the monkeys are selective in their diet and exhibit preferences for different food items in different months and seasons. Out of 25 food plant species, only 10 were eaten most and these included trees, shrubs and climbers. The feeding time devoted to each species in different months and the rank of preference for the species was determined (Table 2).

In March, the most preferred food item was flowers of Sterculia villosa. Flowers of Bombax ceiba were the second preference and flower buds of Ficus religiosa were third. Flowers of Sterculia villosa were also preferred in April. Flower buds of Ficus bengalensis and flowers of Bombax ceiba were at second and third place in order of preference. In May, preference for food items altered with the fruits of Ficus racemosa followed by fruits of Ficus bengalensis and Altingia excelsa was the third preference. In June, the order of first preference became reversed of that of May. However, the Syzygium syzygioides and Morus laevigata were eaten first time in this month. In July the food item was dominated by Syzygium syzygioides and Syzgium cumini. During July and August, the monkeys ate together different plant species as compared to the previous months. Hence, the monthly variation in food plant preference and diet composition became evident. As the season of study was wet, the availability of food resource was not the factor to influence the selectivity of food plants. The study gives a real time situation on field information that can be utilized for habitat assessment and management.
Table 1. Plant species and their parts

\begin{tabular}{|c|c|c|c|}
\hline Local name & Scientific name & Family & Part eaten \\
\hline Udal & Sterculia villosa* & Sterculiaceae & $\mathrm{F}, \mathrm{FL}$ \\
\hline Bogipoma & Chukrasia tabularis* & Meliaceae & $\mathrm{F}, \mathrm{P}$ \\
\hline Outega & Dillenia indica* & Dilleniaceae & $\mathrm{F}$ \\
\hline Amalakhi & Emblica officinalis* & Euphorbiaceae & $\mathrm{F}, \mathrm{ML}, \mathrm{YL}$ \\
\hline Beganala & Lindera sebifera* & & $\mathrm{F}, \mathrm{ML}$ \\
\hline Kodi & Polyalthia jenkinsii & Annonaceae & $M L$ \\
\hline Pani jamun & Syzygium syzygioides* & Myrtaceae & $\mathrm{F}, \mathrm{YL}$ \\
\hline Okani nimora & Unidentified & & $Y L$ \\
\hline Aam & Mangifera indica* & Anacardiaceae & $\mathrm{F}, \mathrm{YL}, \mathrm{FL}$ \\
\hline Sinduri & Mallotus philippinensis* & Euphorbiaceae & $Y L, F$ \\
\hline Pipal & Ficus religiosa* & Moraceae & $\mathrm{F}, \mathrm{YL}, \mathrm{FB}$ \\
\hline Umar & Ficus racemosa * & Moraceae & $F, Y L$ \\
\hline Bargad & Ficus bengalensis* & Moraceae & $\mathrm{F}, \mathrm{P}$ \\
\hline Semul & Bombax ceiba* & Bombacaceae & $\mathrm{F}, \mathrm{FL}, \mathrm{YL}$ \\
\hline Bahera & Terminelia belerica & Combretaceae & $\mathrm{F}, \mathrm{ML}$ \\
\hline Jamun & Syzygium cumini* & Myrtaceae & $\mathrm{F}, \mathrm{YL}, \mathrm{FL}$ \\
\hline Ber & Zizyphus mauritiana* & Rhamnaceae & $F, Y L$ \\
\hline Jiya & Lannea coromandelia* & Anacardiceae & $\mathrm{F}, \mathrm{ML}$ \\
\hline Makania lata & Mikania mikrantha & Compositae & YL. \\
\hline Jutuli & Altingia excelsa* & Hamamelidaceae & $\mathrm{F}, \mathrm{ML}$ \\
\hline Gamari & Gmelina arborea & Verbenaceae & $\mathrm{YL}, \mathrm{ML}$ \\
\hline Hollok & Terminelia myriocarpa & Combretaceae & $\mathrm{FL}$ \\
\hline Pichhola & Kydia calycina & Malvaceae & $\mathrm{FL}, \mathrm{YL}$ \\
\hline Bhola & Morus laevigata & Moraceae & $Y L, M L$ \\
\hline Maifak & Euodia galbrifolia & Rutaceae & $M L, Y L$ \\
\hline
\end{tabular}

* Plant in flowering and fruiting condition during the study period.

YL - Young leaves; ML - mature leaves; F - fruits, FL - flowers; FB - flower bud; $P$ - petioles 


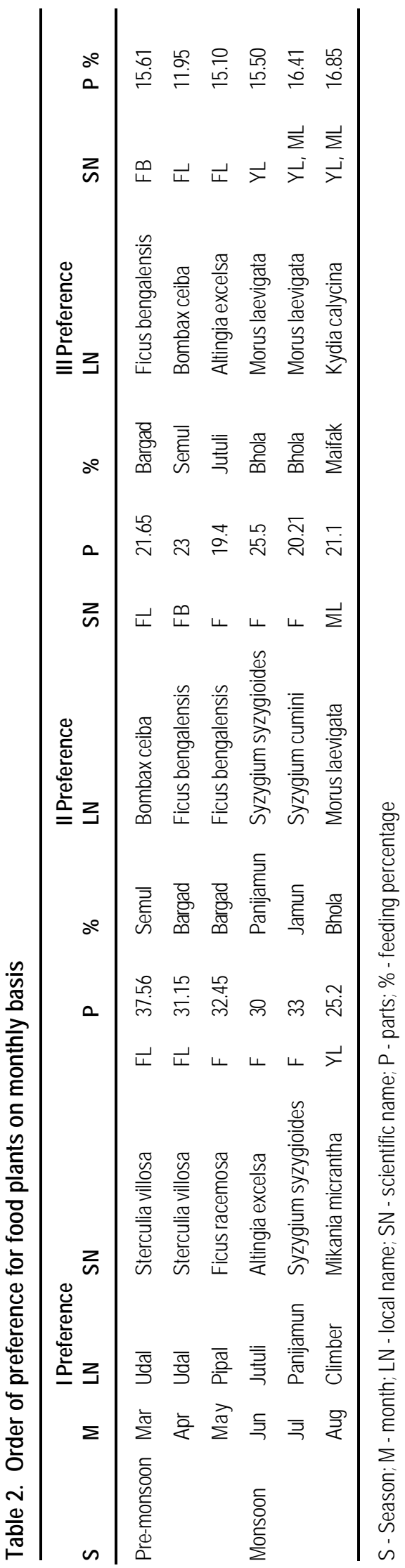

\section{Acknowledgements}

The authors are thankful to Ministry of Environment and Forest (GOI) for providing financial help for the study. We are highly grateful to Director of the Institute, Head, Department of Applied Science (Forestry) for providing necessary facilities for carrying out the study. Our gratitude is also accorded to Principal Chief Conservator of Forest, Government of Arunachal Pradesh for providing permission to work in the protected area.

\section{References}

Altmann, J. (1974). Observational study of behaviour: sampling method. Behaviour 49: 227-267.

Goldstein, S.J. and A.F. Richard (1989). Ecology of Rhesus macaques (Macaca mulatta) in northwest Pakistan. International Journal of Primatology 10(6): 531-567.

Lindburg, D.G. (1971). The Rhesus monkey in North India: An Ecological and Behavioural Study. In: Rosenblum (Editor). Primate behaviour: Development in field and Laboratory Research, Vol. 2, Academic Press, New York.

Makwana, S.C. (1978). Field ecology and behaviour of the Rhesus Macaques, Macaca mulatta. 1. Group composition, home range, roosting sites and foraging routes in the Asarori Forest. Primates 19(3): 483-492.

Makwana, S.C. (1979). Field ecology and behaviour of the Rhesus Macaques, Macaca mulatta. 2. Food, feeding and drinking in the Asarori Forest. Indian Journal of Forestry 2(3): 242-253.

Mandal, A.K. (1995). The behaviour of Rhesus monkeys (Macaca mulatta Zimmermann) in Sundarbans. Journal of the Bombay Natural History Society 33: 153-156.

Neville, D.G. (1968). Ecology and activity of Himalayan foot hill Rhesus monkeys. Ecology 49: 110-123.

Prater, S.H. (1971). The Book of Indian Mammals ( ${ }^{\text {rd }}$ Ed.). Oxford University, Oxford.

Rowe, N. (1996). The Pictorial Guide of the Living Primates. New York: Pogonias Press.

Srivastava, A. (1999). Primates of Northeast India, Megadiversity press, Bikaner, Rajasthan, 208pp.

Seth, P.K., S. Seth, G.L. Reddy and P.K. Chopra (1992). Population trends in naturally occurring Rhesus Monkey populations in different habitats in India. Primate Report 32: 61-73.

Tiwari, K.K. and R.P. Mukharjee (1992). Population census of Rhesus macaques and Hanuman langurs in India. Records of Zoological Survey of India 92(1-4): 349-369. 